\title{
Evaluation of the frequency and patterns of thyroid dysfunction in patients with metabolic syndrome
}

\author{
Gehad Abd El-Shaker Abd El-Hay*, Salah Abdelazim Argoon and Naglaa Mohamed M. A. Mousa
}

\begin{abstract}
Background: Metabolic syndrome (MetS) and thyroid dysfunction have a degree of close association, and each of them affects the other. Due to the associated cardiovascular events, MetS has increased morbidity and mortality. The study tried to detect the frequency of thyroid function in patients with MetS. This is a case control study that recruited 100 patients with MetS and 100 healthy control subjects.

Results: Patients with MetS had significantly higher body mass index and waist circumference. Also, frequency of thyroid dysfunction was significantly higher in MetS group (32\% vs. 9\%; $P<0.001$ ). The most frequent form of thyroid dysfunction was subclinical hypothyroidism: $21 \%$ of the MetS group and $6 \%$ of the control group. Out of the studied patients with MetS, 13 (13\%) patients had three criteria, 55 (55\%) patients had four criteria, and 32 (32\%) patients had five criteria for MetS.

Conclusion: Patients with MetS are vulnerable to develop thyroid dysfunction mainly subclinical hypothyroidism. So, it is recommended to perform regular screening for those patients as regard thyroid dysfunction.
\end{abstract}

Keywords: Thyroid dysfunction, Metabolic syndrome, Hypothyroidism

\section{Background}

Patients with thyroid dysfunction (TD) are vulnerable to cardiovascular disease (CVD). It is known that thyroid hormones have great effects on homeostasis, energy control, and metabolism. TD is known as any deviation in the level of hormones secreted by the thyroid gland [1-3]

Till now, the accurate association of TD with MetS is still a matter of controversy and clinical challenge. Increased frequency of CVD is known to be higher if both of them are present with subsequently increased risk of mortality [4].

Each of TD and MetS has common events as dyslipidemia, central obesity, and diabetes mellitus. Serious outcome may occur with bad prognosis in patients with MetS and missed TD [5]. This work was designed to assess pattern of TD in patients with MetS.

\footnotetext{
* Correspondence: ahmed.111@aun.edu.eg

Department of Internal Medicine, Assiut University Hospital, Faculty of Medicine, Assiut University, Assiut, Egypt
}

\section{Methods \\ Study setting and design}

A case control study was conducted in the period between 2016 and 2018. It was performed at outpatient clinics of diabetes and endocrinology unit.

\section{Participants}

The study recruited 100 patients who fulfilled criteria of MetS based on the National Cholesterol, Education Program, Adult Treatment Panel III (NCEP-ATP III revised 2005) criteria [6]. Age- and sex-matched 100 healthy subjects were enrolled who did not have full criteria of MetS as non-MetS group. Any patient with history of respiratory disease, malignancy, smoking, congestive cardiac failure, pregnant women, and patients under treatment of any thyroid related disorders were excluded.

All participants were subjected to the following:

Through clinical evaluation and examination, body mass index (BMI) and waist circumference (WC) were

Springer Open

(c) The Author(s). 2021 Open Access This article is licensed under a Creative Commons Attribution 4.0 International License, which permits use, sharing, adaptation, distribution and reproduction in any medium or format, as long as you give appropriate credit to the original author(s) and the source, provide a link to the Creative Commons licence, and indicate if changes were made. The images or other third party material in this article are included in the article's Creative Commons licence, unless indicated otherwise in a credit line to the material. If material is not included in the article's Creative Commons licence and your intended use is not permitted by statutory regulation or exceeds the permitted use, you will need to obtain permission directly from the copyright holder. To view a copy of this licence, visit http://creativecommons.org/licenses/by/4.0/. 
assessed. The following laboratory data were done with obtaining a blood samples after $10 \mathrm{~h}$ of fasting: (1) fasting blood glucose, (2) lipid profile, and (3) thyroid hormones: triiodothyronine (T3), thyroxin (T4), and thyroid-stimulating hormone (TSH). TD was classified as explained at Table 1 [7].

\section{Statistical analysis}

SPSS (Statistical Package for the Social Science, version 20, IBM, and Armonk, NY) was used for data analysis. Student's t test and $\mathrm{Chi}^{2}$ test were used to compare continuous and nominal data, respectively. In case of comparison of continuous data of more than two groups, ANOVA was used. Correlation of thyroid hormones with components of metabolic syndrome was assessed by Pearson correlation. The level of confidence was kept at $95 \%$; hence, a $P$ value $<0.05$ indicated a significant association.

\section{Results}

Baseline data of enrolled groups (Table 2)

Both studied groups had no significant difference as regard age and sex distribution, but patients with MetS had significantly higher body mass index, waist circumference, and blood pressure in comparison to the control groups.

\section{Baseline laboratory data among the studied groups (Table 3)}

FBG was significantly higher among MetS group (139.51 \pm 14.32 vs. $83.16 \pm 6.81 \mathrm{mg} ; P<0.001)$. Also, there were significant differences in all parameters of lipid profile between both studied groups. Patients with metabolic syndrome had significantly higher TSH and free T4 in comparison to control group.

\section{State of thyroid function among enrolled groups (Tables 4 and 5)}

TD was more frequent in MetS group (32\% vs. 9\%; $P<$ 0.001). Subclinical hypothyroidism, subclinical hyperthyroidism, and overt hypothyroidism presented in $21 \%$, $6 \%$, and $5 \%$ of MetS group respectively and $6 \%, 2 \%$, and $1 \%$ of the control group respectively.

Based on the number of metabolic criteria among the MetS group, those patients were further subgrouped into

Table 1 Different classes of thyroid dysfunction

\begin{tabular}{llllll}
\hline & \multicolumn{2}{l}{ Hyperthyroidism } & & \multicolumn{2}{c}{ Hypothyroidism } \\
\cline { 2 - 3 } & Overt & Subclinical & & Overt & Subclinical \\
\hline TSH $(\mu \mathrm{u} / \mathrm{ml})$ & $<0.45$ & $<0.45$ & & $>4.50$ & $>4.50$ \\
Free T4 $(\mathrm{ng} / \mathrm{dl})$ & $>0.18$ & $0.80-1.8$ & & $<0.80$ & $>1.80$ \\
Free T3 $(\mathrm{pg} / \mathrm{ml})$ & $>4.4$ & $1.4-4.4$ & & $<1.40$ & $1.4-4.4$ \\
\hline
\end{tabular}

$T S H$, thyroid-stimulating hormone; $F T 4$, free thyroxine; $F T 3$, free triiodothyronine
Table 2 Baseline data of enrolled groups

\begin{tabular}{llll}
\hline & $\begin{array}{l}\text { MetS group } \\
(\mathbf{n}=100)\end{array}$ & $\begin{array}{l}\text { Control group } \\
(\mathbf{n}=\mathbf{1 0 0})\end{array}$ & $\boldsymbol{P}$ value \\
\hline Age (years) & $51.88 \pm 5.86$ & $48.86 \pm 10.24$ & 0.87 \\
Sex & & & 0.07 \\
$\quad$ Male & $40(40 \%)$ & $49(49 \%)$ & \\
$\quad$ Female & $60(60 \%)$ & $51(51 \%)$ & \\
Body mass index $\left(\mathrm{kg} / \mathrm{m}^{2}\right)$ & $36.37 \pm 3.98$ & $31.07 \pm 4.62$ & $<0.001$ \\
Waist circumference $(\mathrm{cm})$ & $105.25 \pm 7.50$ & $99.68 \pm 11.92$ & $<0.001$ \\
SBP $(\mathrm{mmHg})$ & $165.01 \pm 10.20$ & $123.10 \pm 9.067$ & $<0.001$ \\
DBP $(\mathrm{mmHg})$ & $98.05 \pm 5.68$ & $75.30 \pm 10.19$ & $<0.001$ \\
\hline
\end{tabular}

Data was expressed in the form of frequency (percentage), mean (SD). $P$ value was significant if $<0.05$

MetS, metabolic syndrome; $S B P$, systolic blood pressure; $D B P$, diastolic blood pressure

the following: 13 (13\%) patients had three criteria, 55 (55\%) patients had four criteria, and $32(32 \%)$ patients had five criteria. These subgroups had insignificant difference as regard status of thyroid function $(P>0.05)$ (Table 5).

\section{Correlation of thyroid hormones with components of metabolic syndrome (Table 6)}

TG level in the blood has significant positive correlation with TSH ( $\mathrm{r}=0.33 ; P=0.02)$, and FBG has significant positive correlation with T3 $(\mathrm{r}=0.22 ; P=0.02)$. Also, TG level in the blood has significant positive correlation with T4 $(\mathrm{r}=0.24 ; P=0.02)$, and waist circumference has significant negative correlation with $\mathrm{T} 4(\mathrm{r}=-0.26 ; P=$ 0.01). Other correlations were insignificant (Fig. 1).

\section{Discussion}

This work was designed to assess frequency of TD in patients with MetS. BMI, WC, and blood pressure were

Table 3 Baseline laboratory data among the studied groups

\begin{tabular}{|c|c|c|c|}
\hline & $\begin{array}{l}\text { MetS group } \\
(n=100)\end{array}$ & $\begin{array}{l}\text { Control group } \\
(n=100)\end{array}$ & $P$ value \\
\hline $\begin{array}{l}\text { Fasting blood glucose } \\
(\mathrm{mg} / \mathrm{dl})\end{array}$ & $139.51 \pm 14.32$ & $83.16 \pm 6.81$ & $<0.001$ \\
\hline Cholesterol (mg/dl) & $213.29 \pm 49.82$ & $165.66 \pm 17.92$ & $<0.001$ \\
\hline Triglyceride (mg/dl) & $177.49 \pm 39.44$ & $122.64 \pm 18.22$ & $<0.001$ \\
\hline $\begin{array}{l}\text { High-density lipoprotein } \\
\text { (mg/dl) }\end{array}$ & $45.20 \pm 7.01$ & $48.95 \pm 4.95$ & 0.03 \\
\hline $\begin{array}{l}\text { Low-density lipoprotein } \\
\text { (mg/dl) }\end{array}$ & $150.41 \pm 21.51$ & $95.41 \pm 16.45$ & $<0.001$ \\
\hline VLDL (mg/dl) & $29.31 \pm 2.23$ & $24.47 \pm 3.63$ & 0.03 \\
\hline TSH $(\mu \mathrm{u} / \mathrm{ml})$ & $5.24 \pm 1.80$ & $3.24 \pm 1.61$ & $<0.001$ \\
\hline Free T3 (pg/ml) & $3.36 \pm 0.63$ & $3.70 \pm 1.01$ & 0.39 \\
\hline Free T4 (ng/dl) & $1.39 \pm 0.33$ & $1.12 \pm 0.32$ & $<0.001$ \\
\hline
\end{tabular}

Data was expressed in the form of mean (SD). $P$ value was significant if $<0.05$ MetS, metabolic syndrome; VLDL, very low-density lipoprotein; $T S H$, thyroidstimulating hormone; FT4, free thyroxine; $F T 3$, free triiodothyronine 
Table 4 Status of thyroid function among enrolled groups

\begin{tabular}{llll}
\hline & $\begin{array}{l}\text { MetS group } \\
(\mathbf{n}=\mathbf{1 0 0})\end{array}$ & $\begin{array}{l}\text { Control group } \\
(\mathbf{n}=\mathbf{1 0 0 )}\end{array}$ & $\boldsymbol{P}$ value \\
\hline Thyroid dysfunction & $32(32 \%)$ & $9(9 \%)$ & $<0.001$ \\
Subclinical hypothyroidism & $21(21 \%)$ & $6(6 \%)$ & \\
Subclinical hyperthyroidism & $6(6 \%)$ & $2(2 \%)$ & \\
Overt hypothyroidism & $5(5 \%)$ & $1(1 \%)$ & \\
\hline
\end{tabular}

Data expressed as frequency (percentage). $P$ value was significant if $<0.05$ Mets metabolic syndrome

higher among MetS group in the current study. In line with these results, Ahmad et al. [8] stated that MetS group had significantly BMI, WC, age, and blood pressure in comparison to the control group. In the current study, $60 \%$ of MetS group was females, and this was consistent with other studies [9].

We found that MetS group had significantly higher FBG and TG. This may be due to the associated insulin resistance and impaired glucose tolerance in those patients [10]. MetS group had significantly higher TSH and free T4. These findings were similar to findings of Aljabri et al. [11].

In the current work, $13(13 \%)$ patients of MetS group had three criteria of Mets while 55 (55\%) had four criteria, and 32 (32\%) had five criteria. No significant difference as regard thyroid function and TD was noticed among different groups of patients based on number of criteria. Luna-Vazquez et al. [12] found variable correlations between serum TSH, thyroid hormones, and components of the MetS.

TG level in the blood was positively correlated with TSH and T3 while FBG has positive correlation with T3. Delitala et al. [13] stated a positive correlation between TSH with TG, free thyroxine with HDL, and blood pressure with FBG while FT4 had negative correlation with WC.

Effect of thyroid hormones on the metabolism of lipid could be explained through (1) induced transcription of LDL receptor gene, expression of hydroxyl

Table 5 Frequency of thyroid dysfunction based on criteria of metabolic syndrome

\begin{tabular}{|c|c|c|c|}
\hline & $\begin{array}{l}\text { Three criteria } \\
(n=13)\end{array}$ & $\begin{array}{l}\text { Four criteria } \\
(n=55)\end{array}$ & $\begin{array}{l}\text { Five criteria } \\
(n=32)\end{array}$ \\
\hline \multicolumn{4}{|l|}{ Thyroid status* } \\
\hline Euthyroid & $9(69.3 \%)$ & $38(69 \%)$ & $21(65.6 \%)$ \\
\hline $\begin{array}{l}\text { Subclinical } \\
\text { hyperthyroidism }\end{array}$ & $1(7.7 \%)$ & $3(5.5 \%)$ & 2 (6.3\%) \\
\hline $\begin{array}{l}\text { Subclinical } \\
\text { hypothyroidism }\end{array}$ & $3(23 \%)$ & $10(18.2 \%)$ & $8(25 \%)$ \\
\hline Overt hypothyroidism & 0 & $4(7.3 \%)$ & 1 (3.1\%) \\
\hline
\end{tabular}

Data was expressed in the form of frequency (percentage). $P$ value was significant if $<0.05$

*No significant difference
Table 6 Correlation of thyroid hormones with metabolic syndrome components

\begin{tabular}{|c|c|c|c|c|c|c|}
\hline & \multicolumn{2}{|l|}{ TSH } & \multicolumn{2}{|c|}{ Free T3 } & \multicolumn{2}{|c|}{ Free T4 } \\
\hline & $r$ & $P$ & $r$ & $P$ & $r$ & $P$ \\
\hline Systolic blood pressure (mmHg) & 0.04 & 0.63 & 0.05 & 0.59 & 0.09 & 0.34 \\
\hline Diastolic blood pressure (mmHg) & 0.05 & 0.57 & 0.01 & 0.90 & -0.17 & 0.08 \\
\hline Waist circumference (cm) & 0.01 & 0.88 & 0.02 & 0.82 & -0.26 & 0.01 \\
\hline Fasting blood glucose (mg/dl) & 0.06 & 0.49 & 0.22 & 0.02 & 0.03 & 0.73 \\
\hline Triglyceride (mg/dl & 0.33 & 0.02 & 0.14 & 0.14 & 0.24 & 0.02 \\
\hline High density lipoprotein (mg/dl) & 0.08 & 0.41 & 0.04 & 0.67 & -0.06 & 0.51 \\
\hline
\end{tabular}

Data was expressed in the form of $r$ (indicates strength of correlation) and $P$ (indicates significance of correlation). $P$ value was significant if $<0.05$ $T S H$, thyroid-stimulating hormone; FT4, free thyroxine; FT3,

free triiodothyronine

methylglutaryl coenzyme A reductase, and finally upregulation of sterol regulatory element-binding protein-2 [13]. Also, reduction in level of FT4 is associated with visceral obesity and increased insulin resistance. In addition to, high risk of MetS was found in patients with elevated TSH levels [14-16].

We found that patients with MetS had higher frequency of thyroid dysfunction ( $32 \%$ vs. $9 \% ; P<0.001$ ) mainly in the form of subclinical hypothyroidism. Raposo et al. [17] concluded that prevalence of hypothyroidism, hyperthyroidism, and undiagnosed dysfunction was $4.9 \%, 2.5 \%$, and $72.2 \%$, respectively in MetS patients.

Khatiwada et al. [7] stated that subclinical hypothyroidism $(26.6 \%)$ was the most frequent form of TD followed by overt hypothyroidism (3.5\%) and subclinical hyperthyroidism (1.7\%) in MetS patients. Also, Deshmukh et al. [18] found that $28 \%$ of the patients were diagnosed with TD with a higher prevalence among women compared to men. The predominance of hypothyroidism suggests that MetS could be a result of various grades of hypothyroidism during the natural course of the disease. In agreement with our findings, prevalence of hypothyroidism was $29.3 \%$ (7.4\% had overt hypothyroidism and $21.9 \%$ had subclinical hypothyroidism) in previously reported study [19].

Also, Khalil et al. [20] revealed a high frequency (30.19\%) of missed TD in patients with MetS. The most frequent form was hypothyroidism that affected $90.6 \%$ of those with TD. Wang et al. [21] reported that TD accounted $7.21 \%$ of MetS patients. Up to $5 \%$ had subclinical hypothyroidism, and $2.64 \%$ had subclinical hyperthyroidism.

The lesser number of subclinical hypothyroidism cases reported in such study by Wang et al. [21] could be attributed to enrolment of patients with known cases of hypothyroidism who were on levothyroxine therapy.

Yet, another study in Taiwan by Lai et al. [22] concluded the overall prevalence of TD was $7.60 \%$ with $2.10 \%$ to be subclinical hypothyroid and $5.50 \%$ to be subclinical hyperthyroid patients. 


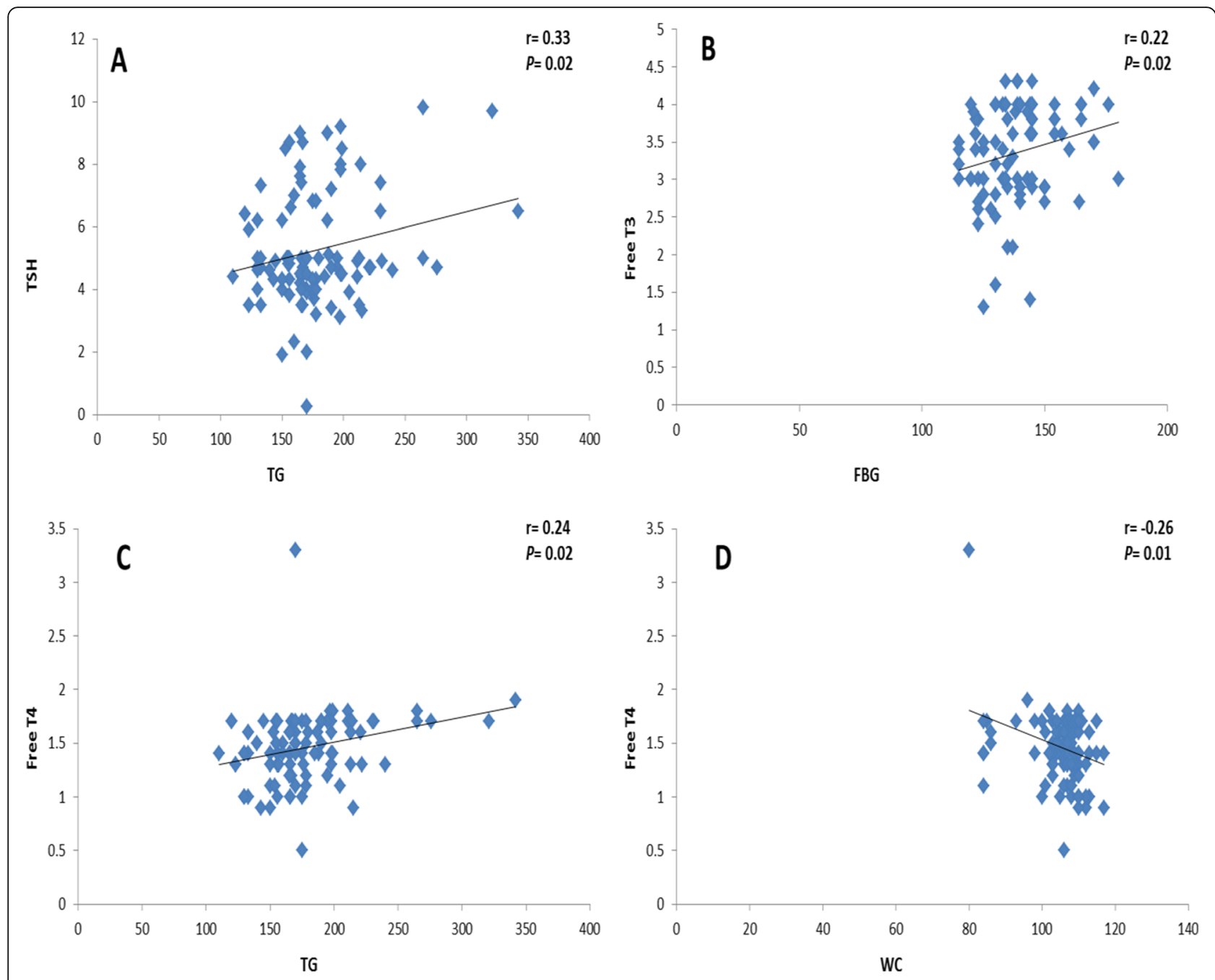

Fig. 1 Correlation between A TG and TSH, B FBG and free T3, C TG and free T4, and D WC and free T4. TSH, thyroid-stimulating hormone; FT4, free thyroxine; FT3, free triiodothyronine; TG, triglyceride; WC, waist circumference; FBG, fasting blood glucose

\section{Conclusion}

We concluded that TD is common with MetS. Therefore, screening for TD in patients with MetS should be done. This allows the early identification of TD with early intervention with subsequent good prognosis.

\section{Abbreviations}

TD: Thyroid dysfunction; MetS: Metabolic syndrome; TSH: Thyroid-stimulating hormone; FT4: Free thyroxine; FT3: Free triiodothyronine; TG: Triglyceride; LDL: Low-density lipoproteins; HDL: High-density lipoproteins; VLDL: Very low-density lipoproteins; BMI: Body mass index; WC: Waist circumference; FBG: Fasting blood glucose

\section{Acknowledgements}

Not applicable

\section{Authors' contributions}

S.A.A. conceived and designed the research. G.A.E.A.E.H. recruited patients, and collected patients' clinical and laboratory data. N.M.M.A.M. and

G.A.E.A.E.H. prepared the original draft of the manuscript and participated in data analysis and writing. The authors read and approved the final manuscript.

\section{Funding}

Not applicable

\section{Availability of data and materials}

The datasets used and/or analyzed during the current study are available from the corresponding author on reasonable request.

\section{Declarations}

\section{Ethics approval and consent to participate}

The study protocol was approved by the Ethics Review Board of Faculty of Medicine, Assiut University, and informed written consent was obtained from all participants according to the Declaration of Helsinki. The committee's reference number is 17100051. Clinicaltrails.gov ID: NCT03214068

\section{Consent for publication}

Not applicable

Competing interests

The authors declare that they have no competing interests. 
Received: 16 February 2021 Accepted: 1 June 2021

Published online: 02 August 2021

\section{References}

1. Ramachandran A, Snehalatha C, Satyavani K, Sivasankari S, Vijay V (2003) Metabolic syndrome in urban Asian Indian adults-a population study using modified ATP III criteria. Diabetes Res Clin Pract 60(3):199-204. https:// doi.org/10.1016/S0168-8227(03)00060-3

2. Liu YY, Brent GA (2010) Thyroid hormone crosstalk with nuclear receptor signaling in metabolic regulation. Trends Endocrinol Metab 21(3):166-173. https://doi.org/10.1016/j.tem.2009.11.004

3. Roos A, Bakker SJ, Links TP, Gans RO, Wolffenbuttel BH (2007) Thyroid function is associated with components of the metabolic syndrome in euthyroid subjects. J Clin EndocrinolMetab 92(2):491-496. https://doi.org/1 $0.1210 /$ jc.2006-1718

4. Chrousos GP (2000) The role of stress and the hypothalamic-pituitaryadrenal axis in the pathogenesis of the metabolic syndrome: neuroendocrine and target tissue-related causes. Int J Obes Relat Metab Disord 24(Suppl 2):S50-S55

5. Park SB, Choi HC, Joo NS (2011) The relation of thyroid function to components of the metabolic syndrome in Korean men and women. J Korean Med Sci 26(4):540-545. https://doi.org/10.3346/jkms.2011.26.4.540

6. Rezaianzadeh A, Namayandeh SM, Sadr SM (2012) National cholesterol education program adult treatment panel III versus international diabetic federation definition of metabolic syndrome, which one is associated with diabetes mellitus and coronary artery disease? Int J Prev Med 3(8):552

7. Khatiwada S, Sah SK, Rajendra KC, Baral N, Lamsal M (2016) Thyroid dysfunction in metabolic syndrome patients and its relationship with components of metabolic syndrome. Clin Diabet Endocrinol 2(1):1-5

8. Ahmad N, Nagtilak S, Parashar P, Sharma AK, Rastogi A, Ahmad M (2018) Thyroid dysfunction in patients with metabolic syndrome and its relationship with components of metabolic syndrome. International journal of Biomedical Research 9(7):259-62. https://doi.org/10.7439/ijbr.v9i7.4805

9. Ogbonna SU, Ezeani IU (2019) Risk factors of thyroid dysfunction in patients with type 2 diabetes mellitus. Front Endocrinol 10:440. https://doi.org/10.33 89/fendo.2019.00440

10. Fauci $A S$, Braunwald $E$, Kasper DL, Hauser SL, Longo DL, Jameson JL et al (2012) Harrison's principles of internal medicine, 18th edn. McGraw-Hill, USA

11. Aljabri KS, Alnasser IM, Bokhari SA, Alshareef MA, Khan PM, Mallosho AM et al (2019) Association between hypothyroidism and chronic kidney disease in patients with type 2 diabetes mellitus in Saudi Community based hospital retrospective single centre study. EC Diabet Metabol Res 3(2):44-49

12. Luna-Vazquez F, Cruz-Lumbreras R, Rodriguez-Castelan J, CervantesRodriguez M, Rodriguez-Antolin J, Arroyo-Helguera O et al (2014) Association between the serum concentration of triiodothyronine with components of metabolic syndrome, cardiovascular risk, and diet in euthyroid post-menopausal women without and with metabolic syndrome. Springerplus 3(1):266. https://doi.org/10.1186/2193-1801-3-266

13. Delitala AP, Scuteri A, Fiorillo E, Lakatta EG, Schlessinger D, Cucca F (2019) Role of adipokines in the association between thyroid hormone and components of the metabolic syndrome. J Clin Med 8(6):764. https://doi. org/10.3390/jcm8060764

14. Kommareddy S, Lee SY, Braverman LE, Pearce EN (2015) Thyroid function and metabolic syndrome: a cross-sectional study in obese and overweight patients. Endocr Pract 21(11):1204-1210. https://doi.org/10.4158/EP15739.OR

15. Fontenelle LC, Feitosa MM, Severo JS, Freitas TE, Morais JB, Torres-Leal FL, Henriques G, do Nascimento Marreiro D (2016) Thyroid function in human obesity: underlying mechanisms. HormMetab Res 48(12):787-794. https:// doi.org/10.1055/s-0042-121421

16. Balercia G, Bonomi M, Giagulli VA, Lanfranco F, Rochira V, Giambersio A et al (2019) Thyroid function in Klinefelter syndrome: a multicentre study from KING group. J Endocrinol Investig 25:1-6

17. Raposo L, Martins S, Ferreira D, Guimarães JT, Santos AC (2019) Metabolic syndrome, thyroid function and autoimmunity-the PORMETS study. Endocrine, Metabol Imm Disor Drug Targets 19(1):75-83

18. Deshmukh V, Farishta F, Bhole M (2018) Thyroid dysfunction in patients with metabolic syndrome: a cross-sectional, epidemiological, Pan-India study. Int J Endocrinol 25

19. Shantha GP, Kumar AA, Jeyachandran V, Rajamanickam D, Rajkumar K, Salim S, Subramanian KK, Natesan S (2009) Association between primary hypothyroidism and metabolic syndrome and the role of $C$ reactive protein: a cross-sectional study from South India. Thyroid Res 2(1):1-7

20. Khalil OA, Awad M, Selim FO, Sadek AM, Fawzy MS (2018) Thyroid dysfunction in patients with metabolic syndrome in medical ICU of Zagazig university hospitals. Benha Med J 35:350-355

21. Wang JY, Wang CY, Pei D, Lai CC, Chen YL, Wu CZ, Chang YL, Hsu CH, Pei C, Tang SH (2010) Association between thyroid function and metabolic syndrome in elderly subjects. J Am Geriatr Soc 58(8):1613-1614. https://doi. org/10.1111/j.1532-5415.2010.02998.x

22. Lai CC, Tang SH, Pei D, Wang CY, Chen YL, Wu CZ, Hsiao FC, Chen HS, Wang JY (2011) The prevalence of subclinical thyroid dysfunction and its association with metabolic syndrome in Taiwanese elderly. Int J Gerontol 5(1):25-29. https://doi.org/10.1016/j.ijge.2011.01.005

\section{Publisher's Note}

Springer Nature remains neutral with regard to jurisdictional claims in published maps and institutional affiliations.

\section{Submit your manuscript to a SpringerOpen ${ }^{\circ}$ journal and benefit from:}

- Convenient online submission

- Rigorous peer review

- Open access: articles freely available online

High visibility within the field

- Retaining the copyright to your article

Submit your next manuscript at $\boldsymbol{\sim}$ springeropen.com 